\title{
Development of an advanced cell therapy product indicated for the treatment of gonarthrosis
}

\author{
Joaquim Vives*, Margarita Blanco, Marta Caminal, Maria I Coca, Margarita Codinach, Ruth Coll, Manuel Doral, \\ Mireia Lloret, Irene Oliver-Vila, Isabel Ortega, Laura Reales, Míriam Requena-Montero, Luciano Rodríguez, \\ Sílvia Torrents, Joan García
}

From 24th European Society for Animal Cell Technology (ESACT) Meeting: C2P2: Cells, Culture, Patients, Products Barcelona, Spain. 31 May - 3 June 2015

\section{Background}

Gonarthrosis is the most common cause of pain and disability in middle-aged and elderly people $[1,2]$. The lack of long-lasting effective treatments for repairing degenerated articular cartilage has spurred research into novel cell-based therapies aiming at reducing pain, slowing the degeneration of cartilage and, ultimately, reverting the natural history of osteoarthritis (OA) [3]. Herein we report the development of a mesenchymal stromal cell (MSC)-based therapy, from conception up to completion of a Phase I/IIa prospective, open-label, single-dose, single-arm clinical trial.

\section{Materials and methods}

All animal care and experimental procedures adhered to the recommendations of local, national, and European laws and were approved by the appropriate Ethical Committees on Human and Animal Experimentation.

A GMP-compliant bioprocess was designed for the production of the investigational cell-based medicinal product. Characterisation of MSC adhered to the minimal criteria established by the International Society for Cellular Therapy [4].

For the clinical study (EUDRA-CT: 2009-016449-24; ClinicalTrials.gov Identifier: NCT01227694), fifteen patients with grade II/ III OA (Kellgren\&Lawrence score [5]) and chronic pain were treated intraarticularly with clinical grade MSC and were followed up to 12 months. Primary endpoints were safety and tolerability. Additionally, therapeutic efficacy was measured by the Visual Analogue Scale (VAS) for daily activity and on exertion [6], Health Assessment Questionnaire (HAQ) [7], the

\footnotetext{
* Correspondence: jvives@bst.cat

Divisió de Teràpies Avançades/XCELIA, Banc de Sang i Teixits, Passeig Taulat
} 116, 08005 Barcelona, Spain

\section{Results and discussion}

Along the development programme, Good Scientific Practice (GxP) quality standards were implemented gradually in our laboratory (Figure 1) [12].

The preclinical package included a proof-of-principle study in a large animal model of chronic OA and three regulatory preclinical studies in murine animal models (Table 1 Figure 1). The intra-articular injection of autologous MSC was safe, as judged by the lack of local or systemic adverse effects and evidence of regeneration of articular cartilage and meniscus was found in specific macroscopic and histological parameters [13]. Three further regulatory preclinical studies were performed in murine animal models in order to 1) assess subchronic toxicology, 2) analyse the biodistribution of human MSC, and 3) investigate dose:response relationship. Our results highlighted the safety of MSC either administered intraarticularly (up to $6 \times 105 \mathrm{MSC} / \mathrm{knee}$ in rats) or intravenously (IV, $1.3 \times 107 \mathrm{MSC} / \mathrm{kg}$ in mice) and the persistence of IV-infused MSC in liver, kidney and spleen, at 3 months post-administration. No tumours were detected in any of the animals during the observation period. IV the liver, eys and spleen of immunocompromised mice. The in spite of receiving a considerable number of cells iately after administration, did not appear to be a welcoming environment adequate for MSC survival, thus confirming other author's observations [14]. 


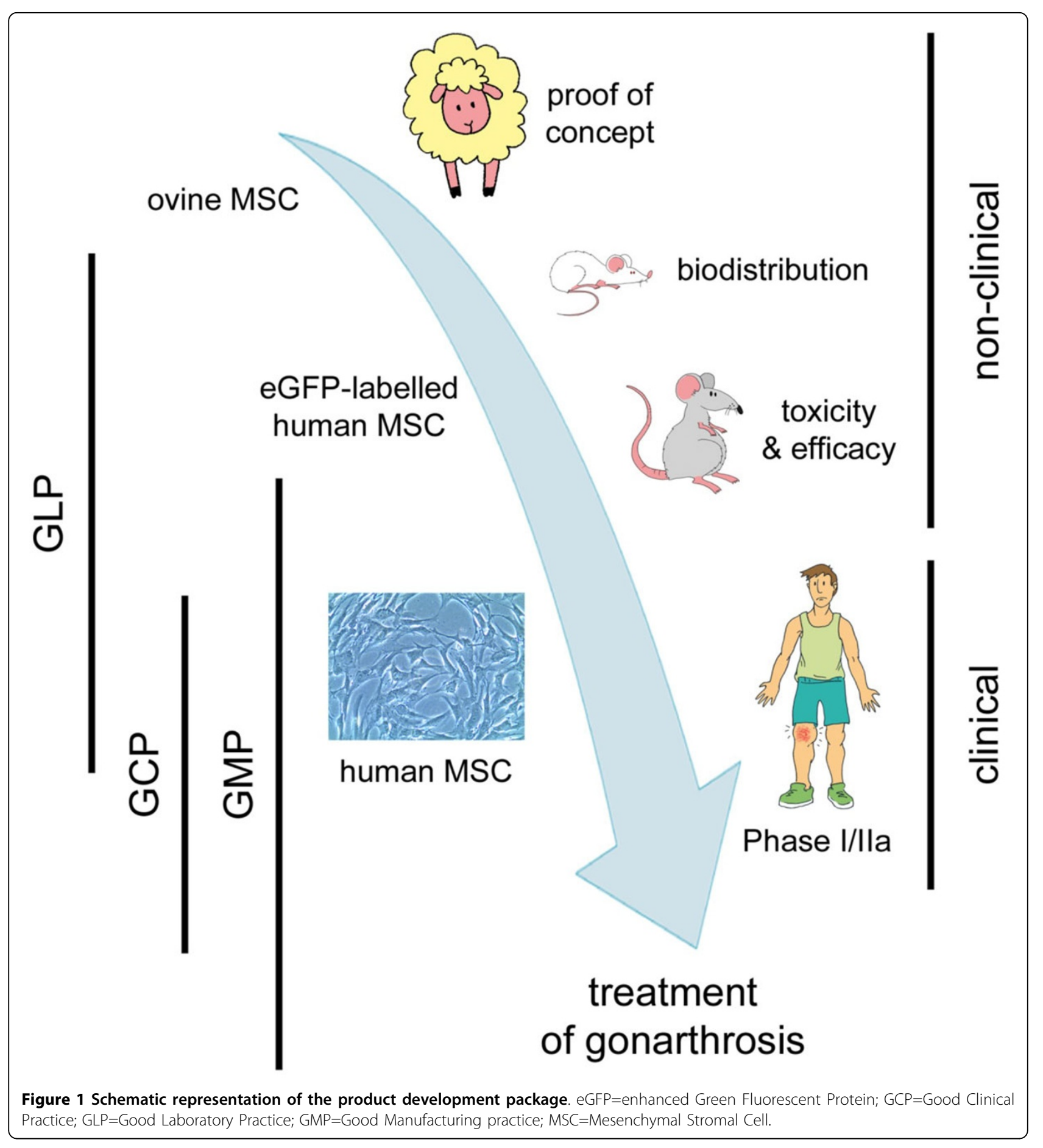

Previous data in large translational animal models [15], and investigations on the role of MSC in cartilage [16,17] and bone [18] regeneration, provided further support with respect to the safety and regenerative qualities of MSC.

For the clinical testing in humans, the drug product consisted in $40.9 \times 106 \pm 0.4 \times 106$ viable MSC in $10.0 \pm$ $0.3 \mathrm{~mL}$ of saline solution. The phenotypic characteristics of the human MSC used in the study were $99.7 \% \pm$
0.2\% CD45-CD105+, 99.0\% \pm 0.6\% CD31-CD73+, $99.9 \pm$ $0.3 \%$ CD90 and $15.5 \% \pm 14.8$ HLA-DR+. The combination of differentiation assays, growth profiles, morphology assessment and cytometric phenotype confirmed the MSC nature of the cells used in our studies. MSC suspensions tested negative for bacteria, mycoplasma and endotoxin before infusion into humans. The analgesic effect of the intra-articular infusion of MSC 
Table 1 Summary of the product development package for a MSC-based medicinal for the treatment of gonarthrosis.

\begin{tabular}{|c|c|c|c|c|c|}
\hline GLP & GMP & GCP & Study description & Experimental system & $\begin{array}{l}\text { Dose; Route of } \\
\text { administration }\end{array}$ \\
\hline & & & $\begin{array}{l}\text { Assessment of long-term effects of autologous MSC treatment in an ovine chronic } \\
\text { model of OA [13] }\end{array}$ & $\begin{array}{l}\text { Ovis aries } \\
\text { (Ripollesa breed, O); } \\
\text { surgically-induced OA }\end{array}$ & $\begin{array}{l}11 \times 10^{6} \text { oMSC; } \\
\text { intraarticular }\end{array}$ \\
\hline \multirow[t]{2}{*}{$x$} & $x$ & & Biodistribution of hMSC in an immunodeficient mouse model & $\begin{array}{l}\text { Mus musculus } \\
\left.\text { (NRG, } \$ \text { and } \sigma^{\circ}\right)\end{array}$ & $\begin{array}{l}4 \times 10^{5} \text { hMSC; }_{i} \\
\text { tail-vein injection }\end{array}$ \\
\hline & $x$ & & Single-dose toxicology study of intraarticularly administered hMSC in athymic rats & $\begin{array}{l}\text { Rattus norvegicus } \\
\text { (NIH nude, ơ) }\end{array}$ & $\begin{array}{l}\text { Up to } 6 \times 10^{5} \\
\text { hMSC; } \\
\text { intraarticular }\end{array}$ \\
\hline$x$ & $x$ & & Dose-response study after intraarticular injection of hMSC in a rat model of OA & $\begin{array}{l}\text { Rattus norvegicus } \\
\text { (NIH nude, o"); } \\
\text { MIA-induced OA }\end{array}$ & $\begin{array}{l}\text { Up to } 8 \times 10^{4} \\
\text { hMSC; } \\
\text { intraarticular }\end{array}$ \\
\hline \multirow[t]{2}{*}{$x$} & $x$ & & $\begin{array}{l}\text { Analysis of protooncogen expression levels, hTERT activity, senescense, G-banding } \\
\text { karyotype, and CGH arrays on clinical grade hMSC }\end{array}$ & In vitro assays & N/A \\
\hline & $x$ & $x$ & $\begin{array}{l}\text { Adult Stem Cell Therapy for Repairing Articular Cartilage in Gonarthrosis (EUDRA- } \\
\text { CT: 2009-016449-24; ClinicalTrials.gov Identifier: NCT01227694) }\end{array}$ & $\begin{array}{l}\text { Human( }\left(Q \text { and } o^{\prime}\right) \text {; grade } \\
\|/\| I \| \text { knee OA }\end{array}$ & $\begin{array}{l}40.9 \times 10^{6} \text { hMSC; } \\
\text { intraarticular }\end{array}$ \\
\hline
\end{tabular}

GXP compliance of non-clinical and clinical studies, and for the production of batches of MSC are also indicated. GCP=Good Clinical Practice; GLP=Good Laboratory Practice; GMP=Good Manufacturing practice; MIA=monoiodoacetate; MSC=Mesenchymal Stromal Cell; OA=osteoarthritis; N/A=Not Applicable; $\mathrm{NIH}=$ National Institutes of Health; NRG=NOD.Cg-Rag $1^{\text {tm } 1 \text { Mom }} \| 12 \mathrm{rg}^{\text {tm } 1 \text { Wjl }} / \mathrm{SzJ}$.

was remarkable, with all patients showing some degree of improvement in daily life physical activity and on exertion at month 12 . Indeed all WOMAC, Lequesne and VAS indexes decreased in a similar manner over time, the most significant changes being observed at 6 and 12 months after treatment. A significant improvement was observed at 12 months in the vitality scale and at 3 months in the global health scale. HAQ decreased significantly from 0.38 at the basal visit to 0.2 at 12 months $(\mathrm{p}<0.05)$, thus indicating a global improvement of the perceived health status.

With respect to cartilage integrity, T2 values decreased significantly over time in all patients. These results may be indicative of regeneration of the articular cartilage in all patients at 1 -year post-treatment. The fact that no pathological values were observed at 12 months in prior healthy areas highlighted the preventive effect of MSC on further degeneration.

\section{Conclusions}

We successfully designed and executed a reproducible GMP-compliant bioprocess for the manufacture of cellbased therapeutics. The clinical procedure involved a minimally invasive intervention, which was feasible and safe, resulting in pain relief and preventing further degeneration of articular cartilage.

\footnotetext{
Acknowledgements

The authors would like to express their sincere gratitude to F. Gòdia, JJ. Cairó, and L. Orozcoand his team for their support in this project. This work was supported by grants "Ministerio de Economía y Competitividad" (IPT-3000002010-0017), "Ministerio de Ciencia e Innovación" (PSE-010000-2007-4//PSE010000-2008-4, BIO2008-01985), Spanish Cell Therapy Network(TerCel, RD12/ 0019/0015) and by the European Regional Development Fund, within the
} National Plan for Scientific Research, Development and Innovation 2008-2011.
Published: 14 December 2015

\section{References}

1. Murray CJL, Vos T, Lozano R, Naghavi M, Flaxman AD, Michaud C, Ezzati M, Shibuya K, Salomon JA, Abdalla S, et al: Disability-adjusted life years (DALYs) for 291 diseases and injuries in 21 regions, 1990?2010: a systematic analysis for the Global Burden of Disease Study 2010. The Lancet 2012, 380:2197-2223.

2. Vos T, Flaxman AD, Naghavi M, Lozano R, Michaud C, Ezzati M, Shibuya K, Salomon JA, Abdalla S, Aboyans V, et al: Years lived with disability (YLDs) for 1160 sequelae of 289 diseases and injuries 1990-2010: a systematic analysis for the Global Burden of Disease Study 2010. Lancet 2012, 380:2163-2196.

3. Huey DJ, Hu JC, Athanasiou KA: Unlike bone, cartilage regeneration remains elusive. Science 2012, 338:917-921.

4. Dominici M, Le Blanc K, Mueller I, Slaper-Cortenbach I, Marini F, Krause D, Deans R, Keating A, Prockop D, Horwitz E: Minimal criteria for defining multipotent mesenchymal stromal cells. The International Society for Cellular Therapy position statement.Cytotherapy 2006, 8:315-317.

5. Kellgren JH, Lawrence JS: Radiological assessment of osteo-arthrosis. Ann Rheum Dis 1957, 16:494-502.

6. Huskisson EC: Measurement of pain. Lancet 1974, 2:1127-1131.

7. Esteve-Vives J, Batlle-Gualda E, Reig A: Spanish version of the Health Assessment Questionnaire: reliability, validity and transcultural equivalency. Grupo para la Adaptacion del HAQ a la Poblacion Espanola J Rheumatol 1993, 20:2116-2122.

8. Kosinski M, Keller SD, Ware JE, Hatoum HT, Kong SX: The SF-36 Health Survey as a generic outcome measure in clinical trials of patients with osteoarthritis and rheumatoid arthritis: relative validity of scales in relation to clinical measures of arthritis severity. Med Care 1999, 37:MS23-39.

9. Faucher M, Poiraudeau S, Lefevre-Colau MM, Rannou F, Fermanian J, Revel M: Assessment of the test-retest reliability and construct validity of a modified WOMAC index in knee osteoarthritis. Joint Bone Spine 2004, 71:121-127.

10. Trattnig S, Mamisch TC, Welsch GH, Glaser C, Szomolanyi P, Gebetsroither S, Stastny O, Horger W, Millington S, Marlovits S: Quantitative T2 mapping of matrix-associated autologous chondrocyte transplantation at 3 Tesla: an in vivo cross-sectional study. Invest Radiol 2007, 42:442-448.

11. Crema MD, Roemer FW, Marra MD, Burstein D, Gold GE, Eckstein F, Baum T, Mosher TJ, Carrino JA, Guermazi A: Articular cartilage in the knee: current MR imaging techniques and applications in clinical practice and research. Radiographics 2011, 31:37-61.

12. Vives J, Oliver-Vila I, Pla A: Quality compliance in the shift from cell transplantation to cell therapy in non-pharma environments. Cytotherapy 2015. 
13. Caminal M, Fonseca C, Peris D, Moll X, Rabanal RM, Barrachina J, Codina D, Garcia F, Cairo JJ, Godia F, et al: Use of a chronic model of articular cartilage and meniscal injury for the assessment of long-term effects after autologous mesenchymal stromal cell treatment in sheep. N Biotechnol 2014, 31:492-498.

14. Vilalta M, Degano IR, Bago J, Gould D, Santos M, Garcia-Arranz M, Ayats R, Fuster C, Chernajovsky Y, Garcia-Olmo D, et al: Biodistribution, long-term survival, and safety of human adipose tissue-derived mesenchymal stem cells transplanted in nude mice by high sensitivity non-invasive bioluminescence imaging. Stem Cells Dev 2008, 17:993-1003.

15. Fonseca C, Caminal M, Peris D, Barrachina J, Fabregas PJ, Garcia F, Cairo JJ, Godia F, Pla A, Vives J: An arthroscopic approach for the treatment of osteochondral focal defects with cell-free and cell-loaded PLGA scaffolds in sheep. Cytotechnology 2014, 66:345-354.

16. Caminal M, Moll X, Codina D, Rabanal RM, Morist A, Barrachina J, Garcia F, Pla A, Vives J: Transitory improvement of articular cartilage characteristics after implantation of polylactide:polyglycolic acid (PLGA) scaffolds seeded with autologous mesenchymal stromal cells in a sheep model of critical-sized chondral defect. Biotechnol Lett 2014, 36:2143-2153.

17. Caminal M, Peris D, Fonseca C, Barrachina J, Codina D, Rabanal RM, Moll X, Morist A, Garcia F, Cairo JJ, et al: Cartilage resurfacing potential of PLGA scaffolds loaded with autologous cells from cartilage, fat, and bone marrow in an ovine model of osteochondral focal defect. Cytotechnology 2015.

18. Velez R, Hernandez-Fernandez A, Caminal M, Vives J, Soldado F, Fernandez A, Pla A, Aguirre M: Treatment of femoral head osteonecrosis with advanced cell therapy in sheep. Arch Orthop Trauma Surg 2012, 132:1611-1618.

doi:10.1186/1753-6561-9-S9-09

Cite this article as: Vives et al:: Development of an advanced cell therapy product indicated for the treatment of gonarthrosis. BMC Proceedings 2015 9(Suppl 9):O9.

\section{Submit your next manuscript to BioMed Central and take full advantage of:}

- Convenient online submission

- Thorough peer review

- No space constraints or color figure charges

- Immediate publication on acceptance

- Inclusion in PubMed, CAS, Scopus and Google Scholar

- Research which is freely available for redistribution

Submit your manuscript at www.biomedcentral.com/submit 